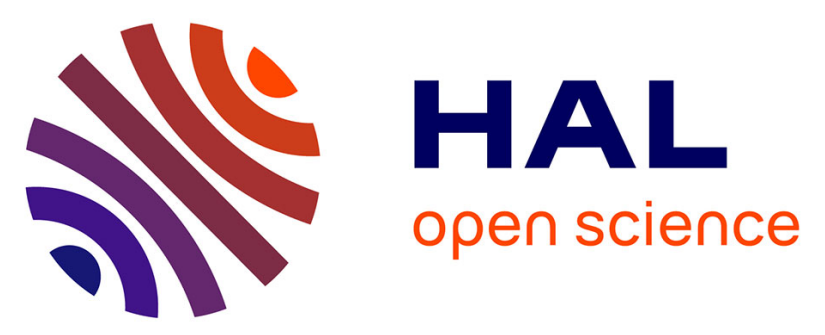

\title{
Transmission Electron Microscope imaging sharpens geochronological interpretation of zircon and monazite
}

Anne-Magali Seydoux-Guillaume, Bernard Bingen, Valérie Bosse, Emilie Janots, Antonin Laurent

\section{- To cite this version:}

Anne-Magali Seydoux-Guillaume, Bernard Bingen, Valérie Bosse, Emilie Janots, Antonin Laurent. Transmission Electron Microscope imaging sharpens geochronological interpretation of zircon and monazite. Desmond E. Moser Fernando Corfu James R. Darling, Steven M. Reddy, Kimberly Tait. Microstructural Geochronology; lattice to atom-scale records of planetary history, AGU book. Moser, D., F. Corfu, S.M. Reddy,J. Darling \& K. Tait. (eds.), Wiley; American Geophysical Union, 2018, Geophysical Monograph Series, 978-1-119-22724-3. 10.1002/9781119227250.ch12 • hal-01928347

\section{HAL Id: hal-01928347 \\ https://hal.science/hal-01928347}

Submitted on 20 Nov 2018

HAL is a multi-disciplinary open access archive for the deposit and dissemination of scientific research documents, whether they are published or not. The documents may come from teaching and research institutions in France or abroad, or from public or private research centers.
L'archive ouverte pluridisciplinaire HAL, est destinée au dépôt et à la diffusion de documents scientifiques de niveau recherche, publiés ou non, émanant des établissements d'enseignement et de recherche français ou étrangers, des laboratoires publics ou privés. 
1 Transmission Electron Microscope imaging sharpens geochronological interpretation of

3 Anne-Magali Seydoux-Guillaume ${ }^{1,2}$, Bernard Bingen ${ }^{3}$, Valérie Bosse ${ }^{1}$, Emilie Janots ${ }^{4}$, and

$4 \quad$ Antonin T. Laurent ${ }^{2}$

$5 \quad{ }^{1}$ Laboratoire Magmas et Volcans, LMV UMR 6524 CNRS, UBP, IRD, Université Blaise Pascal,

6 Clermont-Ferrand, France

$7 \quad{ }^{2}$ Université Lyon, UJM-Saint-Etienne, UBP, CNRS, IRD, Laboratoire Magmas et Volcans UMR 6524,

8 Saint Etienne, France

$9 \quad{ }^{3}$ Geological Survey of Norway, 7491 Trondheim, Norway

$10{ }^{4}$ ISTerre, University Grenoble Alpes, Grenoble, France

\section{Keypoints:}

14 1-Geochronological interpretations benefits from nanoscale characterization of zircon and monazite.

2- TEM provides evidences of the mechanisms behind disturbance of the $\mathrm{U}-\mathrm{Th}-\mathrm{Pb}$

17 geochronological systems resulting is discordant ages.

3- Nano-petrochronology improves the geochronological data interpretation on concordant dates spreading along the concordia curve.

\section{Abstract}

The present paper highlights the benefits of nanoscale characterization of the most commonly used minerals - zircon and monazite - in $\mathrm{U}-\mathrm{Th}-\mathrm{Pb}$ geochronology to sharpen 
geochronological interpretations and convert isotopic ratios - a "date" - into a geologically meaningful age. Transmission Electron Microscopy (TEM) is a powerful analytical tool, and sometimes the only one, that can provide evidence of the mechanisms behind disturbance of the geochronological systems leading to discordance. These mechanisms include (1) distinct episodes of growth/replacement, (2) U, Th or Pb mobility (enhanced by the presence of nanostructural defects), (3) nano-inclusions or nano-chemical heterogeneity. Furthermore, TEM also helps to interpret concordant dates spreading along the Concordia curve. Such spread could represent protracted continuous growth, episodic short-duration growth, or $\mathrm{U}-\mathrm{Th}-\mathrm{Pb}$ disturbance of the geochronometers. In this paper, we show TEM images of nano-inclusions interfering with $\mathrm{U}-\mathrm{Th}-\mathrm{Pb}$ systematics and discuss how to address the impact of nanoinclusions on isotopic dates. Second, we show how experimental studies can be used to understand the mechanism of $\mathrm{U}-\mathrm{Th}-\mathrm{Pb}$ resetting in monazite. Finally, the third part focuses on nano-petrochronology of monazite, i.e. how the identification of nano-chemical tracer revealed by TEM improves the geochronological data interpretation.

Keywords: nanoscale characterization; linking TEM and $\mathrm{U}-\mathrm{Th}-\mathrm{Pb}$ geochronology; resetting mechanism; zircon and monazite; nano-petrochronology

\section{Introduction}

The orthosilicate zircon $\left(\mathrm{ZrSiO}_{4}\right)$ and orthophosphate monazite (Light Rare Earth Element phosphate: $\mathrm{LREEPO}_{4}$ ) are the most widely used minerals in $\mathrm{U}-\mathrm{Pb}$ and $\mathrm{U}-\mathrm{Th}-\mathrm{Pb}$ (only for monazite) geochronology in a variety of geological contexts [Parrish 1990; Harrison et al., 2002; Harley and Kelly, 2007; Corfu, 2013]. Ideally, the two decay chains, ${ }^{238} \mathrm{U} /{ }^{206} \mathrm{~Pb}$, ${ }^{235} \mathrm{U} /{ }^{207} \mathrm{~Pb}$, (and also the third one ${ }^{232} \mathrm{Th} /{ }^{208} \mathrm{~Pb}$ in the case of monazite), yield concordant dates, 
that are straightforwardly interpreted as the age of the zircon or monazite crystallization. However, discordant dates are frequent and indicate disturbance of the isotopic systems after initial crystallization. Yet, even in cases where the $\mathrm{U}-\mathrm{Pb}$ data are entirely concordant, age disturbance cannot be ruled out (e.g. Ashwal et al., 1999). In a specific example from a monazite megacrystal from Arendal, Norway, high-resolution mineral characterization, in particular TEM, revealed partial replacement of primary monazite by secondary monazite due to late-stage alteration [Seydoux-Guillaume et al., 2007 and 2012]. In the secondary altered domains, in-situ $\mathrm{U}-\mathrm{Pb}$ dating leads to concordant dates but meaningless ages, generally older than the primary material, due to contrasting $\mathrm{U}$, Th and $\mathrm{Pb}$ redistribution during alteration. Sometimes, redistribution of the parent elements ( $\mathrm{U}, \mathrm{Th})$, and radiogenic or non-radiogenic $\mathrm{Pb}$ takes place during the history of the mineral, leading to uncertain interpretation [Harrison et al., 2002; Villa and Williams, 2013]. Two critical processes are responsible for $\mathrm{U}-\mathrm{Th}-\mathrm{Pb}$ mobility and thus resetting in minerals: chemical reactions and diffusion [Cole and Chakraborty, 2001]. The relative efficiency and interplay of each of these processes depends mainly on temperature, time, grain-size or surface area, structural state of the lattice (defects induced by deformation and/or radiation damage) and presence of fluid or melt. The response of zircon and monazite to these parameters is briefly examined below.

Zircon is generally reactive (new domains with a size >10's micrometer) in amphibolite-facies metamorphic conditions and beyond [Yakymchuk and Brown, 2014; DesOrmeau et al., 2015; Marsh and Stockli, 2015]. While solid state diffusion can be excluded in well crystallized zircon [Lee et al., 1997; Cherniak and Watson, 2003], zircon Achilles' heel is clearly the accumulation of radiation damage over time, critically affecting zircon physical and chemical properties. Typically, zircon contains $U$ in the hundreds of ppm range, and consequently has received alpha-decay doses on the order of $10^{18}-10^{19} \mathrm{\alpha} / \mathrm{g}$ and is easily amorphized [Ewing et al., 2000; Ewing et al., 2003]. Self-irradiation enhances diffusion 
[e.g. Cherniak and Watson, 2003], facilitates mineral-fluid interaction [e.g. Geisler et al., 2003 and 2007; Nasdala et al., 2010], may lead to possible reduction of $\mathrm{Pb}^{4+}$ to $\mathrm{Pb}^{2+}\left[\mathrm{Kramers}^{2}\right.$ et al. 2009; Tanaka et al., 2010; Kogawa et al., 2012], and more generally can result in open system behavior even at low temperature $\left(<200^{\circ} \mathrm{C}\right)$ and discordance [e.g. Geisler et al., 2007; Xu et al., 2012].

In contrast to zircon, the lattice of monazite is not affected by amorphization over time, in spite of alpha decay doses in the range of $10^{19}-10^{20} \alpha / g$, generated by extremely high concentrations of Th (up to $25 \mathrm{wt} \% \mathrm{ThO}_{2}$ ) and to a lower extent of $\mathrm{U}$ (up to $1 \mathrm{wt} \% \mathrm{UO}_{2}$ ) [Seydoux-Guillaume et al., 2004]. Clear evidence of radiation damage is limited to isolated nm-sized domains within monazite crystal. Mottled diffraction contrast in TEM is a very characteristic feature of monazite, resulting from a mosaic structure of the crystal, i.e., a lattice comprising many smaller domains with slightly different orientations. [Black et al., 1984; Meldrum et al., 1998; Seydoux-Guillaume et al., 2002b; 2003; 2004]. Solid-state diffusion of $\mathrm{U}$, Th and $\mathrm{Pb}$ is insignificant up to high temperature conditions [Cherniak et al., 2004; Gardés et al., 2006; Gardés et al., 2007] and monazite can therefore yield precise ages without any isotopic disturbances after crystallization, at least under most crustal conditions. However, monazite is well known for its reactivity in the presence of fluids, even at low temperature [e.g. Poitrasson et al., 1996; 2000; Rasmussen et al., 2001; Bollinger and Janots, 2006; Janots et al., 2006; 2008; 2011; Seydoux-Guillaume et al., 2012; Allaz et al., 2013; Didier et al., 2013]. Commonly monazite crystals show patchy compositional zoning. Each zone corresponds to a distinct crystallization event recording changes that took place during the history of the host rock. These changes can be metamorphic solid-state reactions [e.g. destabilization of feldspar, crystallization of garnet; e.g. Rubatto et al., 2001], reaction with a silicate melt, fluid-rock interaction during alteration, metamorphism or metasomatism [e.g. Heinrich et al., 1997; Finger and Krenn 2007; Harlov et al., 2011; Janots et al., 2012; Didier et 
al., 2013; Gauthiez-Putallaz et al., 2016], or dynamic recrystallization in response to deformation event [Erickson et al., 2015 and 2016]. This reactivity of monazite covers a large range of P-T-fluids conditions [Spear and Pyle, 2002] ranging from low grade metamorphism [Rasmussen and Muhling, 2007; Janots et al., 2006; 2008; 2011], granulite-facies metamorphism [Kelly et al., 2012; Kirkland et al., 2016], to magmatic conditions [Rubatto et al., 2013; Dumond et al., 2015; Wang et al., 2015]. In monazite, complex compositional zoning attests to successive crystallization events, either growth of new monazite and/or replacement of a previous one. These zones can be dated individually using microanalytical methods - Electron Microprobe analysis (EPMA), Secondary Ion Mass Spectrometry (SIMS), or Laser Ablation Inductively Coupled Plasma Mass Spectrometry (LA-ICP-MS) - and used to reconstruct the reaction history of the rock [e.g. Williams et al., 1999; 2007; 2012; Janots et al., 2012; Kelly et al., 2012].

The steady development in micro-sampling methods (SIMS, LA-ICP-MS, EPMA), now routinely applied for in situ dating of zircon and monazite, requires clear evaluation of the balance between analytical precision, analytical volume and effective volume of closed system behavior of the isotopic systems [Corfu, 2013; Nemchin et al., 2013; Schoene et al., 2013]. Any mobility of $\mathrm{U}$, Th or $\mathrm{Pb}$ at a significant scale relative to the analytical volume or any overlap of the analytical volume between two volumes characterized by distinct isotopic closure leads to a disturbance, a modification of the initial crystallization age, or an analytically induced mixed age. In this context, Corfu [2013], based on the results of Moser et al. [2009], showed the benefit applying several analytical methods, with contrasted precision and microsampling performances, on the same geochronological problem, to provide arguments for correct interpretation of the data. In that specific case, the more precise IDTIMS data are discordant but plot on a discordia line, whereas the less precise SIMS data all overlap the Concordia curve within error. Nano-petrochronology, is the characterization of 
samples at different scales, including the nanometer scale [Kusiak et al., 2015; SeydouxGuillaume et al., 2012 and 2015; Didier et al., 2015; Darling et al., 2016] or even atomic scale [Valley et al., 2014; Valley et al., 2015; Peterman et al., 2016; Piazolo et al., 2016] in order to link the mineral properties (nanostructure and nanoscale compositional heterogeneities) with geochronological data. Because Transmission Electron Microscopy (TEM) is the only technique able to combine nano-structural and nano-chemical information, it can provide evidences for the resetting mechanism of geochronological systems by identifying remnant of chemical reactions (e.g. secondary grains products and nano-inclusions; coupled dissolutionprecipitation interface; pore filled with fluid/mineral/melt) or structural defects enhancing diffusion and alteration processes (e.g. amorphisation, plastic deformation). Insights from nano-characterization thus help to validate or invalidate the interpretation of an isotopic ratio (a "date") into a geologically meaningful age. In the case of mineral replacement, it is common that the replaced domain contained tiny crystals (micrometric to nanometric) of distinct mineral phases [Figure 1 and review in Putnis, 2009]. For example, the presence of nanocrystals of thorite $\left(\mathrm{ThSiO}_{4}\right)$ in apatite (Figure 1A-B) or uraninite $\left(\mathrm{UO}_{2}\right)$ in zircon $($ Figure 1C) compromises $\mathrm{U}-\mathrm{Th}-\mathrm{Pb}$ or $\mathrm{U}-\mathrm{Th} / \mathrm{He}$ dating. In the presence of fluid, primary monazite can react to form a secondary, Th-U-depleted monazite, typically accompanied by numerous thorite/huttonite $\left(\mathrm{ThSiO}_{4}\right)$ and/or thorianite $\left(\mathrm{ThO}_{2}\right)$ inclusions [Hetherington and Harlov, 2008; Seydoux-Guillaume et al., 2012; Figure 1D]. In inclusion-rich altered domains, inaccurate ages, measured by EPMA or LA-ICP-MS, results from the presence of numerous nano-phases and nano-fractures filled with Th-U-silicates that are visible only under TEM [Seydoux-Guillaume et al., 2012; Figure 1D]. Information coming from such nanocharacterization may, however, help to improve the interpretation of dates. In this paper, we focus on zircon and monazite characterization with TEM and how it can sharpen interpretation of $\mathrm{U}-\mathrm{Th}-\mathrm{Pb}$ geochronological data. The paper is divided in three parts: the first 
part presents examples of nano-inclusions that interfere with the $\mathrm{U}-\mathrm{Th}-\mathrm{Pb}$ systematics and how we can address them; the second part is dedicated to experimental studies and how they simulate the resetting of the $\mathrm{U}-\mathrm{Th}-\mathrm{Pb}$ systems in monazite; and the third part focuses on a micro- to nano-chemical tracer that may help to improve the interpretation of geochronological data.

\section{Sample preparation.}

Because TEM requires very thin samples, less than $100 \mathrm{~nm}$ thick, sample preparation for TEM characterization is one critical and essential step to obtain reliable analyzes. The development of the Focused Ion Beam (FIB) technique for TEM preparation has considerably opened the possibilities for TEM characterization, especially for the geoscience community, for which imaging of tiny phases or inclusions, microstructures or interfaces in situ, in their thin section context, is often crucial. The FIB preparation allows to produce site-specific TEM foils, typically $10-15 \mu \mathrm{m}$ large over $5-10 \mu \mathrm{m}$ in depth and less than $0.1 \mu \mathrm{m}$ thick slice, cut perpendicular to the surface of a (c. $30 \mu \mathrm{m}$ thick) petrographic thin section. The FIB is the sole technique that allows cutting TEM-ready foils with homogeneous sample thickness, in a section from a well-defined area such as mineral boundary, without preferential thinning or production of artifacts. Many examples and details of the technique are reviewed in Wirth [2004 and 2009]. Nowadays, most of the TEM studies are closely associated and dependent from FIB preparations.

3. Structural and chemical evidence for nano-inclusions affecting the $\mathbf{U}-\mathbf{T h}-\mathbf{P b}$ systematics in monazite and zircon.

\subsection{Zircon}


Microscope- (STEM-HAADF) imaging [Utsunomiya et al., 2004]. The authors found nanoscale patches rich in $\mathrm{Pb}$ in two locations: inside the zircon lattice (concentrated at 3 at $\%$ ) and inside amorphous domains from fission tracks. They suggested that beyond the first percolation point [Salje et al., 1999; Trachenko et al., 2003; Geisler et al., 2007], when amorphous domains overlap and form an interconnected network, $\mathrm{Pb}$ will diffuse faster in zircon. These observations were confirmed a few years later by Utsunomiya et al. [2007] using the same technique. Even if the first percolation point will differ a little depending on the thermal history of the sample [Geisler et al., 2003], the dose is estimated to be of $2.2 \mathrm{x}$ $10^{18} \alpha / g$ [Pidgeon, 2014]. Beyond the first percolation point, the probability of enhanced $\mathrm{Pb}$ mobility in response to an external event, like for example metamorphism, is very high.

Lead mobility in polymetamorphic zircon of the Napier complex of Enderby Land, Antarctica, was documented earlier through SIMS micro-analysis by Black et al. [1986]. In the same sample, these authors observed reverse and normal discordance of the $\mathrm{U}-\mathrm{Pb}$ isotopic system, attesting for $\mathrm{Pb}$ mobility with simultaneous $\mathrm{Pb}$ loss or $\mathrm{Pb}$ gain depending on the analytical spot. The nature and size of isotopic perturbation in high-grade polymetamorphic samples were recently addressed using SIMS imaging [Kusiak et al., 2013; Whitehouse et al., 2014], and TEM [Kusiak et al., 2015]. Thanks to HAADF-TEM and electron diffraction patterns, Kusiak et al. [2015] identified nanospheres of metallic $\mathrm{Pb}, 5$ to $30 \mathrm{~nm}$ in diameter, randomly distributed in those zircons (Figure 2C-D). The nanospheres are commonly associated with an amorphous silica-rich phase and $\mathrm{Ti}$ - and Al-rich phases, interpreted to be melt inclusions formed during ultra-high temperature metamorphism. The patchy-distribution of $\mathrm{Pb}$ highlighted with SIMS imaging [Kusiak et al., 2013; Figure 2B] causes the spreading of discordance and $\mathrm{U}-\mathrm{Pb}$ ages (Figure $2 \mathrm{~A}$ ), and can be attributed to the presence of metallic $\mathrm{Pb}$ - 
nanospheres in zircon [Kusiak et al., 2015]. Identification (type of phase, structure, size, morphology) of these nanospheres was feasible thanks to the combination of nano-structural and nano-chemical analyzes, only achievable with TEM. In contrast, the Atom Probe Tomography (APT) would not provide structural information, and would only reveal the presence of $\mathrm{Pb}$-nanoclusters and their isotopic composition [e.g. Peterman et al., 2016; Piazolo et al., 2016]. Their metallic nature can only be determined using nano-diffraction with TEM [Kusiak et al., 2015]. In this example, TEM characterization helps to prove that apparent ages as old as $4.2 \mathrm{Ga}$ do not correspond to relicts of ancient zircons (and thus have no geological meaning), but to $\mathrm{Pb}$ migration and coalescence into $\mathrm{Pb}$ metallic nanosphere during the recovery of crystallinity in radiation-damaged zircon under high-grade metamorphism [Kusiak et al., 2015]. Such redistribution of radiogenic $\mathrm{Pb}$ at the nanoscale may compromise the precision and accuracy of $\mathrm{U}-\mathrm{Pb}$ obtained by high-resolution in situ methods like SIMS, as shown by Kusiak et al., [2013] and Whitehouse et al. [2014]. When larger analytical volumes are considered (e.g. by LA-ICP-MS or SIMS), the effect of the nanoscale heterogeneities may decrease. In Kusiak et al. [2013], the dates obtained with the highest spatial resolution $(2 \mu \mathrm{m})$ generates meaningless age up to $4198 \mathrm{Ma}$ [Figure 2B], whereas analyzes with typical SIMS spot size of c. $15 \mu \mathrm{m}$ yield broad distribution of ages between 3324 and 3605 Ma [Figure 3F in Kusiak et al., 2013]. This leads thus to the question of what should be the optimal spatial resolution for in situ analyses?

Mobility of the parent element $\mathrm{U}$ in zircon has also been documented by SeydouxGuillaume et al., [2015] using STEM-HAADF and STEM-Energy Dispersive X-Ray Spectroscopy (EDS) analyses coupled with $\mathrm{U}-\mathrm{Pb}$ isotopic analysis. In a pegmatite from Norway [Duran et al., 2016], atypical zircon phenocrysts are affected by intense selfirradiation, associated with amorphization, microporosity, swelling, radial cracking, and uptake of non-formula cations like Ca. Fractures and pores represent the vectors for fluid 
mediated open system behavior. This alteration leads to increased discordance of the $\mathrm{U}-\mathrm{Pb}$ system (Figure 3A-B). Again, STEM (HAADF and EDS) analyses demonstrate the presence of U-rich (uraninite) clusters $(<70 \mathrm{~nm})$ within the porosity and of high density walls $(<50$ $\mathrm{nm}$ ), enriched in $\mathrm{U}$ or $\mathrm{Ca}$ or both, coating the pores (Figure 3C-D). It is only the close association of nano- characterization (TEM) to the geochronological data [SeydouxGuillaume et al., 2015; Figure 3] that allows to interpret the spatial link between U, Ca and porosity as evidence for $\mathrm{U}$ uptake, and which demonstrates that discordance of the $\mathrm{U}-\mathrm{Pb}$ system in zircon affected by radiation damage includes a component of U- mobility (U-gain U-loss).

Both examples by Kusiak et al., [2015] and Seydoux-Guillaume et al., [2015] are notes of the promising role of nano-petrochronology for geochronological studies, especially when ages are discordant. They demonstrate how careful nano-scale characterization, associating the U$\mathrm{Pb}$ analytical data with their structural context, may avoid spurious age interpretation. $\mathrm{A}$ meaningful age cannot be extracted from all zircon grains, because some are likely to be affected by radiation damage and/or chemical reactions, which will cause and enhance $\mathrm{Pb}$ and U mobility.

\subsection{Monazite}

Monazite is much less studied than zircon and, as far as we know, few studies attempted to link TEM characterization to geochronological interpretation. Black et al. [1984] focused on monazite from polymetamorphic rocks of the Napier complex in Antarctica. The authors tried to link the color of monazite grains (brown, yellow and grey) with the nanostructure (TEM) and the discordance. Independently of the color, all monazite crystals present the same nanostructure, i.e. $100 \AA$ crystalline domains misoriented from each other by 
no more than $2 \times 10^{-3}$ radians, leading to mottled diffraction contrasts on Bright Field or Dark Field (BF/DF)-TEM images. Such observation is typical for monazite crystals and the mottled contrast is attributed to radiation damage and was confirmed later by Seydoux-Guillaume et al. [2004] in a comparison between different monazite samples (from 24 Ma to 2 Ga). To address the problem of inconsistent electron-microprobe (EPMA) chemical ages in complex monazite from a polymetamorphic granulite (Andriamena unit, Madagascar, SeydouxGuillaume et al. [2003] linked a TEM study with electron-microprobe U-Th-Pb chemical dating. The presence of 50nm Pb-rich inclusions is revealed in monazite domains where large variations in EPMA dates are detected (Figure 4). The nature of these inclusions is not completely understood, but it was proposed that they could be a $\mathrm{Pb}-\mathrm{Ca}-\mathrm{Si}-\mathrm{O}$ phase like margarosanite $\left(\mathrm{Ca}_{2} \mathrm{PbSi}_{3} \mathrm{O}_{9}\right)$ or more probably represent material that crystallized in fluid inclusions (Figure 4B-C). The TEM study led to a new interpretation of EPMA dates for monazite previously considered to be the result of partial $\mathrm{Pb}$ loss from a $2.5 \mathrm{Ga}$ monazite. The scatter of apparent ages ranging from $2.5 \mathrm{Ga}$ to $790 \mathrm{Ma}$ (Figure 4A) is reinterpreted to result from the replacement of a primary monazite by a secondary monazite during a metamorphic event at $790 \mathrm{Ma}$ with random incorporation of various amount of $\mathrm{Pb}$-rich inclusions in the analytical volume of the EPMA analysis in secondary monazite domains. The presence of $\mathrm{Pb}$ rich inclusions suggests that recrystallization of monazite does not result, in this case, in a total removal of previously accumulated radiogenic $\mathrm{Pb}$, but partial preservation in $\mathrm{Pb}$-rich clusters. This study therefore exemplifies that domains of unsupported $\mathrm{Pb}$ can exist in monazite. This result was recently confirmed by several studies [e.g. Seydoux-Guillaume et al., 2012; Didier et al., 2013], that also suggest that Pb-rich nano-inclusions (or nanodomains) could contain a non-radiogenic $\mathrm{Pb}$ component. 


\section{Nanoscale constrains on the resetting mechanism of $\mathrm{U}-\mathrm{Th}-\mathrm{Pb}$ systems in} experimentally altered monazite.

The first experimental study addressing the hydrothermal resetting of the $\mathrm{U}-\mathrm{Pb}$ systems in monazite was performed in 1997 by Teufel and Heinrich [1997] in pure water. Partial resetting of the U-Pb systems was evaluated by multigrain ID-TIMS analysis of the experimental products. Partial resetting was only detected for a starting material made of fine monazite powder $(<1-15 \mu \mathrm{m})$ and could be shown to be the result of monazite dissolution and precipitation of neoformed monazite. The maximum $\mathrm{Pb}$ loss of 26\% (ID-TIMS dating of the experimental product) was observed at the highest temperature $\left(750^{\circ} \mathrm{C}\right)$. A major revelation of this study was that dissolution and precipitation is more efficient than volume diffusion [Cherniak et al., 2004; Gardès et al., 2006 and 2007] to reset the U-Pb clock in monazite. Seydoux-Guillaume et al. [2002], confirmed the importance of the dissolution-precipitation mechanism by performing a series of experiments $\left(800-1200^{\circ} \mathrm{C}\right)$ using different fluid compositions. Monograins $(200-400 \mu \mathrm{m})$ of the experimental products were analyzed by IDTIMS, EPMA and SIMS show that 1) partial resetting was obtained only in the presence of Ca-rich fluid at $1000^{\circ} \mathrm{C}$ and involved dissolution followed by precipitation of $\mathrm{Pb}$-free neoformed monazite; 2) experiments with $\mathrm{Pb}$-bearing fluid produced sub-concordant monazite for which the ${ }^{207} \mathrm{~Pb} /{ }^{206} \mathrm{~Pb}$ apparent ages were older than the primary monazite used for the experiment, demonstrating that monazite may incorporate $\mathrm{Pb}$ from a fluid. This last result is consistent with TEM observations by Seydoux-Guillaume et al. [2003] that Pb-rich nano-domains observed in monazite samples from Madagascar may be incorporated from a fluid phase and may explain contamination by common $\mathrm{Pb}$ recorded in some natural monazites [e.g. Didier et al., 2013; Janots et al., 2012; Seydoux-Guillaume et al., 2012].

Based on natural observations that metasomatic alteration of monazite is particularly developed in Na- and K-rich geological environments [Harlov et al., 2007; Hetherington and 
Harlov, 2008], monazite alteration experiments were performed in the presence of Na- or Krich fluids, with different ligands, starting material and temperature [Harlov and Hetherington, 2010; Hetherington et al., 2010; Harlov et al., 2011; Williams et al., 2011; Budzyn et al., 2011; 2015; Shazia et al., 2016]. All these experimental studies show that alkali fluids are the most efficient fluids to promote monazite replacement, even for temperature as low as $250^{\circ} \mathrm{C}$ [Budzyn et al., 2016]. Under these conditions, the monazite texture of experimentally replaced monazite is typical of those encountered in natural systems. It shows a secondary rim, that is normally porous, and with a composition that differs of the original monazite starting material. This replacement process is now believed to be preponderant in numerous natural environments (diagenetic, metamorphic or hydrothermal).

Using TEM characterization, Harlov et al. [2011] could demonstrate that the replacement of experimental products is caused by an interfacially coupled dissolutionprecipitation mechanism [e.g. Putnis and Putnis, 2007; Putnis 2009]. Indeed, TEM observations reveal a sharp reaction interface between primary domains (starting material with radiation damage) and secondary domains free of radiation damage, with negligible evidence of diffusion even at the nanoscale. These experimental studies also indicate that the physicochemical conditions of the fluid play an important role on the $\mathrm{U}-\mathrm{Th}-\mathrm{Pb}$ resetting in secondary monazite. Remarkably, the $\mathrm{U}-\mathrm{Th}-\mathrm{Pb}$ system is not systematically reset and $\mathrm{Pb}$ is present in altered domain produced in presence of $\mathrm{NaOH}$ or $\mathrm{KOH}$ fluids [Harlov et al., 2011] or $\mathrm{Na}_{2} \mathrm{SiO}_{5}$ bearing fluids below $350^{\circ} \mathrm{C}$ [Budzyn et al., 2015]. However, $\mathrm{Pb}$ was close or below the detection limit in monazite altered domain produced in presence of $\mathrm{Na}_{2} \mathrm{SiO}_{5}$ bearing fluids at $450^{\circ} \mathrm{C}$ [Williams et al., 2011] or in presence of $\mathrm{K}$ - and Na-rich melts at $800^{\circ} \mathrm{C}$ [Shazia et al., 2016]. As a consequence such altered chemical domains may be dated by in situ techniques [EPMA in Williams et al., 2011] and thus offer a great potential to date metasomatic events. 
Recently, progress done on high spatial resolution in situ analytical techniques (e.g. LA-ICP-MS), and on the development of site specific preparation (FIB-Focused Ion Beam) for TEM analyses, allow Grand'Homme et al., [2016b] to formulate a new hypothesis to explain partial resetting observed in experimentally altered monazite samples $\left(300-600^{\circ} \mathrm{C}\right)$ under alkali conditions. Experimentally altered monazite rims (Figure 5B; at $500^{\circ} \mathrm{C}$ ), dated using in situ techniques (EPMA and LA-ICP-MS) systematically yield intermediate dates (Figure 5A; EPMA) between pristine monazite (555 Ma) and complete experimental resetting (0 Ma), with a mean date that decreases with increasing temperatures (down to $71 \pm 27 \mathrm{Ma}$ at $600^{\circ} \mathrm{C}$ ). Nanometric characterizations using TEM of experimental products elucidated the origin of this partial resetting. At such nanoscale, the replacement is incomplete within the altered rim (Figure 5C): altered rim corresponds to a nano-mixture of $\mathrm{Pb}$-free (EDS-TEM) secondary monazite (mnz2), with inherited monazite (mnz1). No Pb-bearing inclusions were observed in the altered domain. The partial resetting depends then on the nano-mixture of different proportion of mnz1 in the analyzed volume (Figure 5C). Even in the case of EPMA analyses, where the interaction volume is the smallest $\left(<35 \mu \mathrm{m}^{3}\right.$; but with no way to have a 3D control during the analysis), a scattering of dates exists and lead to erroneous ages (Figure $5 \mathrm{~A} ; 163 \pm 54 \mathrm{Ma}$ at $\left.500^{\circ} \mathrm{C}\right)$. Partial replacement in altered domains certainly applies to monazite naturally replaced in the presence of fluid. Indeed, the experimental results simulate well the microstructures of fluid-driven replacements (skeletal structures, microporosity, inclusion) and can account for the age scattering and discordance obtained in altered monazite domains [e.g., Bosse et al., 2009; Kelly et al., 2012; Seydoux-Guillaume et al., 2012; Didier et al., 2013; Grand'Homme et al., 2016a] but also in rock deformed by dislocation creep, where incomplete resetting was proposed but not explained [e.g. Wawrzenitz et al., 2012; Erickson et al., 2015 and 2016]. However, in the case of new monazite (over)growths involving spatially decoupled dissolution and precipitation [e.g. dissolution-precipitation creep in 
deformed rock; Wawrzenitz et al., 2012; Didier et al., 2014; Erickson et al., 2015 and 2016] and experimentally reproduced in Seydoux-Guillaume et al. [2002], such nano-scale incomplete replacement will not occur. It may be challenging to recognize possible disturbances linked with nanomixture, when large age data sets are determined with no reliable micro (to nano)-textural documentation on the dated grains (e.g., as for example in provenance studies).

\section{Nano-petrochronology of monazite.}

The structural flexibility of monazite permits substitution of more than 25 elements of the periodic table in its lattice [Clavier et al., 2011]. Monazite is monoclinic with space group $\mathrm{P} 21 / \mathrm{n}$ and its structure is organized in chains, parallel to c-axis, with alternating $\mathrm{PO}_{4}$ tetrahedrons and $\mathrm{REEO}_{9}$ polyhedrons [Ni et al., 1995; Boatner, 2002; Clavier et al., 2011]. The nine-fold site preferentially incorporates LREE, but may accommodate a large variety of other (possibly larger) cations, especially Th, U, and Ca by two well-documented substitution types [Förster, 1998; Montel et al., 2002; Clavier et al., 2011]. The cheralite $\left[\mathrm{CaTh}\left(\mathrm{PO}_{4}\right)_{2}\right.$; formerly called brabantite] exchange $\mathrm{An}^{4+}+\mathrm{M}^{2+}=2 \mathrm{REE}^{3+}-$ with $\mathrm{An}=(\mathrm{Th}, \mathrm{U})$ and $\mathrm{M}=(\mathrm{Ca}$, $\mathrm{Ba}, \mathrm{Sr}, \mathrm{Pb})$ - involving the nine-fold site alone and the huttonite $\left(\mathrm{ThSiO}_{4}\right)$ exchange $\mathrm{An}^{4+}+$

$\mathrm{Si}^{4+}=2 \mathrm{REE}^{3+}+\mathrm{P}^{5+}$ that involve both sites. Furthermore, $\mathrm{Y}$ and HREE are incorporated through the xenotime $\left(\mathrm{YPO}_{4}\right)$ substitution; this property allows monazite to be used as a thermometer when associated with xenotime [Gratz and Heinrich, 1997; Heinrich et al., 1997; Seydoux-Guillaume et al., 2002b] and with garnet [Pyle et al., 2001]. More exotic cations may be incorporated into monazite lattice; these include $\mathrm{S}$ incorporated as anhydrite component $\left[\mathrm{CaSO}_{4}\right.$; Chakhmouradian and Mitchell, 1999; Prsek et al. 2010; Krenn et al., 2011], Sr [Krenn et al., 2011; Holder et al., 2015; Prsek et al. 2010], As incorporated as a gasparite component [CeAsO 4 ; Ondrejka et al., 2007; Janots et al., 2006; 2008; 2011; Gnos et 
al., 2015], and V [McFarlane and McKeough, 2013]. The structural incorporation of redoxsensitive elements in monazite opens the perspective of tracing the evolution of the oxidation state through time in a large number of rocks, thanks to the $\mathrm{U}-\mathrm{Pb}$ and $\mathrm{Th}-\mathrm{Pb}$ isotopic systems.

To show the importance of sulfur as a petrogenetic tracer and the contribution of TEM imaging to uncover it, we focus here on complexly patchy zoned monazite crystals (Figure 6A) from an osumilite-bearing granulite from Rogaland, Norway [Laurent et al., 2016], in which in situ $\mathrm{U}-\mathrm{Pb}$ dating (LA-ICP-MS) were performed (Figure 6B). The U-Pb dataset of monazite is concordant to sub-concordant (conc. > $95 \%$ ), with analyses plotting continuously along the concordia curve from ca. 1040 Ma down to 920 Ma (Figure 6B). When considering the chemical composition at both micro- and nano-scale (Figures 6E-F), more specific and useful information can be extracted to interpret the apparently continuous age spread. In the monazite crystals, three chemical domains are distinguished (Figure 6A, C-D): D1, a S-rich core $\left(0.45-0.72 \mathrm{Wt}\right.$ \% $\mathrm{SO}_{2}$-Figure 6D, Th incorporated as cheralite component, i.e. Si-poor Figure 6C), D2, secondary S-bearing domains $\left(\mathrm{SO}_{2}>0.05 \mathrm{Wt}\right.$ \% , partly clouded with solid inclusions-Figure 6A), and D3, late S-free-Figure 6D, Y-rich, domains (0.8-2.5 Wt. $\% \mathrm{Y}_{2} \mathrm{O}_{3}$, Th accommodated as huttonite component, i.e. Si-rich Figure 6C). Nano-characterization of the S-rich monazite domains (D1), using FIB preparation coupled with STEM-HAADF imaging, revealed the presence of black dots (5-10 $\mathrm{nm}$ in size) homogenously distributed all over the foil and representing negative density contrast in monazite (arrow in Figure 6E). High resolution STEM-HAADF image (Figure 6F) demonstrates that these nanoclusters are made of anhydrite $\left(\mathrm{CaSO}_{4}\right)$ characterized by a coherent interface toward the host monazite. These data imply that $\mathrm{S}$ was incorporated in the monazite lattice as a clino-anhydrite component following the exchange $\mathrm{Ca}^{2+}+\mathrm{S}^{6+}=\mathrm{REE}^{3+}+\mathrm{P}^{5+}$, but then is partly exsolved in nanoclusters of $\mathrm{CaSO}_{4}$. Monazite with significant sulfate substitution is expected to crystallize 
395 from oxidized geological fluids or melts in which sulfur is present as $S^{6+}$. The close 396 combination of micro-chemical (EPMA) and nano-structural and nano-chemical (STEM) 397 analyses with $\mathrm{U}-\mathrm{Pb}$ dating allow to attribute precise ages to these three domains. The S-rich 398 core D1 yields a concordia age of $1034 \pm 6 \mathrm{Ma}$, S-bearing D2 gives a significantly younger age of $1005 \pm 7$ Ma and S-free D3 of $935 \pm 7$ Ma (Figures C-D). From regional correlation

400 [Bingen et al., 2008] and sulphide phase-stability diagrams [Whitney et al., 1984], the interpretation is that S-rich monazite cores (D1) crystallized at $1034 \pm 6$ Ma from an oxidized,

402

403

404

405 sulphate $\left(S^{6+}\right)$-dominated granitic melt during fluid-absent partial melting. Monazite may therefore be used to probe the presence of sulfur in anatectic melts from high-grade terrains at a specific point in time and date sulfur mobilization from reduced to oxidized state. This interpretation could be provided only because TEM analyses proves that sulfur substitutes as $\mathrm{CaSO}_{4}$ in monazite lattice, and not as inclusions that may reflect and record other processes than primary crystallization [e.g. in figure 6A, sulfur inclusions in D2 reflect metasomatism event; monazite inclusions in Rasmussen et al., 2011 record metamorphic event).

\section{Conclusions}

This paper highlights how characterization at the nanoscale, with combination of nano-structural and nano-chemical information, using TEM, provides insights to understand the $\mathrm{U}-\mathrm{Th}-\mathrm{Pb}$ systematics of zircon and monazite and improve age geochronological interpretations. This nano- scale characterization, referred as nano-petrochronology, provides information not only on perturbation of the isotopic systems, but it also contributes to understand reaction mechanisms and distribution of petrogenetically important trace elements. This is well illustrated by the input of nano-chemical tracer $\left(\mathrm{CaSO}_{4}\right)$ in monazite or by the presence of $\mathrm{Pb}$ or $\mathrm{U}$ rich-nanophases in monazite and zircon crystals. This nano- 
petrochronology approach could possibly applied to other common $\mathrm{U}-\mathrm{Th}-\mathrm{Pb}$ chronometers (i.e. titanite, allanite).

The paper also raises the question of the optimal spatial resolution for in situ analyses, a critical issue coming from the improvement of the in situ analytical techniques (e.g. LAICP-MS, HR-SIMS, nano-SIMS, EPMA) and well-demonstrated by the studies of Kusiak et al. [2013] and Valley et al. [2014] for zircon, or Seydoux-Guillaume et al. [2003] and [2012] for monazite. We suggest that the use of high-spatially resolved techniques requires even more careful nano-characterization (with TEM) of the samples, to provide reliable geochronological interpretations of the data.

Furthermore, considering the complementarity of the Atom Probe Tomography (APT) technique, which provides isotopic information within nanoscale domains [e.g. Valley et al., 2014; Valley et al., 2015; Peterman et al., 2016; Piazolo et al., 2016] in typical analyzed volumes of material of $50 \times 50 \times 200 \mathrm{~nm}^{3}$, we assert that combination of APT with TEM, a highly complementary technique yielding both nano-structural and nano-chemical information, would considerably improve the interpretation of $\mathrm{U}-\mathrm{Th}-\mathrm{Pb}$ geochronological data; such correlative microscopy should certainly be developed in the future.

The need of experimental data has been demonstrated, in order to better constrain the behavior of parent (e.g. U, Th) and daughter (e.g. $\mathrm{Pb}$ ) elements and the resetting mechanisms under a large range of conditions (P-T-fluids). Indeed, it has been demonstrated for monazite, that incomplete replacement at the nanoscale may lead to partial resetting of the $\mathrm{U}-\mathrm{Th}-\mathrm{Pb}$ systems and thus to meaningless ages. Such experimental studies coupling nanocharacterization with the behavior of isotopic systems (U-Pb but also $\mathrm{Lu}-\mathrm{Hf}$ ) are long overdue for zircon, and, in contrast to monazite, certainly highly dependent on its structural state due to its sensitivity to radiation damage [Geisler et al., 2007]. 


\section{Acknowledgement}

445 The authors thank L. Datas (UMS Castaing, Toulouse), C. Dominici (CP2M-Marseille) and B. Reig (LAAS, Toulouse) for technical assistance. The paper benefited from insightful discussions with many of our students, colleagues, and friends including Amélie Didier, Stéphanie Duchene, Charley Duran, Philippe Goncalves, Alexis Grand'homme, Damien network allows to prepare most of the FIB samples. Collaborations were promoted thanks to PHC Aurora (Ministry of Foreign affairs of France and the Research Council of Norway). provided financial support. We thank Desmond Moser, Editor-in-Chief, S. Reddy, associate editor, A. Cavosie and an anonymous reviewer, whose comments significantly improved the paper.

\section{References}

459

Allaz, J., Selleck, B., Williams, M.L., and Jercinovic, M.J. (2013). Microprobe analysis and dating of monazite from the Potsdam Formation, New York: A progressive record of chemical reaction and fluid interaction. Am. Mineral. 98, 1106-1119.

Ashwal, L.D., Tucker, R.D., and Zinner, E.K. (1999). Slow cooling of deep crustal granulites and Pb-loss in zircon: Geochim. Cosmochim. Acta, 63, 2839-2851.

Bingen, B., Nordgulen, O., and Viola, G. (2008). A four-phase model for the Sveconorwegian orogeny, SW Scandinavia. Nor Geol Tidsskr, 88, 43.

Black, L.P., Fitzgerald, J.D., and Harley, S.L. (1984). Pb isotopic composition, colour, and microstructure of monazites from a polymetamorphic rock in Antarctica. Contrib. Mineral. Petrol., 85, 141-148. 
Black, L. P., Williams, I. S., and Compston, W. (1986). Four zircon ages from one rock: the history of a 3930 Ma-old granulite from Mount Sones, Enderby Land, Antarctica. Contributions to Mineralogy and Petrology, 94, 427-437.

Boatner, L. (2002). Synthesis, Structure, and Properties of Monazite, Pretulite, and Xenotime. In Reviews in Mineralogy and Geochemistry (ed. P. H. Ribbe) 48, pp. 87-121. Mineralogical Society of America.

Bollinger, L., and Janots, E. (2006). Evidence for Mio-Pliocene retrograde monazite in the Lesser Himalaya, far western Nepal. Eur. J. Mineral. 18, 289-297.

Bosse, V., Boulvais, P., Gautier, P., Tiepolo, M., Ruffet, G., Devidal, J.L., Cherneva, Z., Gerdjikov, I., and Paquette, J.L. (2009). Fluid-induced disturbance of the monazite Th-Pb chronometer: In situ dating and element mapping in pegmatites from the Rhodope (Greece, Bulgaria). Chem. Geol., 261, p. 286-302.

Budzyn, B., Harlov, D.E., Williams, M.L., and Jercinovic, M.J. (2011). Experimental determination of stability relations between monazite, fluorapatite, allanite, and REEepidote as a function of pressure, temperature, and fluid composition. Am. Mineral. 96, $1547-1567$.

Budzyn, B., Jastrzebski, M., Kozub-Budzyn, G.A., and Konecny, P. (2015). Monazite Th-Utotal $\mathrm{Pb}$ geochronology and $\mathrm{P}-\mathrm{T}$ thermodynamic modelling in a revision of the HP-HT metamorphic record in granulites from Stary Gieraltow (NE Orlica-Snieznik Dome, SW Poland). Geol. Q. 59, 700-717.

Chakhmouradian, A.R., and Mitchell, R.H. (1999). Niobian ilmenite, hydroxylapatite and sulfatian monazite: alternative hosts for incompatible elements in calcite kimberlite from Internatsional'naya, Yakutia. Can. Mineral. 37, 1177-1189.

Cherniak, D.J., Watson, E.B., 2003. Diffusion in zircon, in: Hanchar, J.M., Hoskin, P.W.O. (Eds.), Zircon. Mineralogical Soc Amer, Chantilly, pp. 113-143.

Cherniak, D.J., Watson, E.B., Grove, M., Harrison, T.M. (2004). Pb diffusion in monazite: a combined RBS/SIMS study. Geochim. Cosmochim. Acta, 68, 829-840.

Clavier, N., Podor, R., and Dacheux, N. (2011). Crystal chemistry of the monazite structure. J. Eur. Cer. Soc., 31, 941-976. 
Cole, D. R., \& Chakraborty, S. (2001). Rates and mechanisms of isotopic exchange. Reviews in Mineralogy and Geochemistry, 43(1), 83-223.

Corfu, F. (2013). A century of U-Pb geochronology: the long quest towards concordance. Geol. Soc. Am. Bull., 125, 33-47.

Darling, J.R., Moser, D.E., Barker, I.R., Tait, K.T., Chamberlain, K.R., Schmitt, A.K., and Hyde, B.C. (2016). Variable microstructural response of baddeleyite to shock metamorphism in young basaltic shergottite NWA 5298 and improved U-Pb dating of Solar system events. Earth Planet. Sci. Lett., 444, 1-12.

DesOrmeau, J.W., Gordon, S.M., Kylander-Clark, A.R.C., Hacker, B.R., Bowring, S.A., Schoene, B., and Samperton, K.M. (2015). Insights into (U)HP metamorphism of the Western Gneiss Region, Norway: A high-spatial resolution and high-precision zircon study: Chem. Geol., 414, 138-155.

Didier, A., Bosse, V., Boulvais, P., Bouloton, J., Paquette, J.-L., Montel, J.-M., and Devidal, J.-L. (2013). Disturbance versus preservation of $\mathrm{U}-\mathrm{Th}-\mathrm{Pb}$ ages in monazite during fluidrock interaction: textural, chemical and isotopic in situ study in microgranites (Velay Dome, France). Contrib. Mineral. Petrol., 165, 1051-1072.

Didier, A., Bosse, V., Cherneva, Z., Gautier, P., Georgieva, M., Paquette, J.L., and Gerdjikov, I. (2014) Syn-deformation fluid-assisted growth of monazite during renewed high-grade metamorphism in metapelites of the Central Rhodope (Bulgaria, Greece). Chem Geol 381:206-222

Didier, A., Bosse, V., Bouloton, J., Mostefaoui, S., Viala, M., Paquette, J.L., Devidal, J.L., and Duhamel R. (2015). NanoSIMS mapping and LA ICP MS chemical and U-Th-Pb data in monazite from a xenolith enclosed in ndesite (Central Slovakia Volcanic Field). Contrib. Mineral. Petrol., 170 doi:10.1007/s00410-015-1200-1.

Dumond, G, Goncalves, P, Williams, ML, and Jercinovic, MJ (2015). Monazite as a monitor of melting, garnet growth, and feldspar recrystallization in continental lower crust. J. Metamorph. Geol. doi: 10.1111/jmg.12150

Duran, C.J., Seydoux-Guillaume, A-M, Bingen, B., Gouy, S., de Parseval, P., Ingrin, J., and Guillaume, D. (2016). Fluid-mediated alteration of (Y,REE,U,Th)-(Nb,Ta,Ti) oxide minerals in granitic pegmatite from the Evje-Iveland district, southern Norway. Min. Petrol., DOI 10.1007/s00710-016-0436-4. 
Erickson, T.M., Cavosie, A.J., Pearce, M.A., Timms, N.E., and Reddy, S. (2016). Empirical constraints on shock features in monazite using shocked zircon inclusions. Geology, 44, 635-638.

Erickson, T.M., Pearce, M.A., Taylor, R.J.M., Timms, N.E., Clark, C., Reddy, S.M. and Buick, I.S. (2015). Deformed monazite yields high-temperature tectonic ages. Geology, 44, $635-638$

Ewing, R.C.,Meldrum, A.,Wang, L.M.,Wang, S.X. (2000): Radiation- induced amorphisation. Rev. Mineral. Geochem., Ribbe P.H., ed., Mineral. Soc. Amer., Washington DC., 39, 319361.

Ewing, R.C., Meldrum, A., Wang, L.M., Weber, W.J., and Corrales, L.R. (2003). Radiation damage in zircon. In: Hanchar, J.M., Hoskin, P.W.O. (Eds.), Zircon. In: Reviews in Mineralogy and Geochemistry, vol.53. Mineralogical Society of America, 387-425.

Finger, F., and Krenn, E. (2007). Three metamorphic monazite generations in a high-pressure rock from the Bohemian Massif and the potentially important role of apatite in stimulating polyphase monazite growth along a PT loop. Lithos 95:103-115.

Förster, H.J. (1998): The chemical composition of REE-Y-Th-U rich accessory minerals in peraluminous granites of the Erzgebirge-Fichtelgebirge region, Germany, Part I: The monazite-(Ce)-brabantite solid solution series. Am. Mineral., 83, 259-272.

Gardés, E., Jaoul, O., Montel, J.-M., Seydoux-Guillaume, A.-M., and Wirth, R. (2006). Pb diffusion in monazite: An experimental study of interdiffusion. Geochim. Cosmochim. Acta, 70, 2325-2336.

Gardés, E., Montel, J.-M., Seydoux-Guillaume, A.M., and Wirth, R. (2007). Pb diffusion in monazite: New constraints from the experimental study of $\mathrm{Pb}^{2+}=\mathrm{Ca}^{2+}$ interdiffusion. Geoch. et Cosmochim. Acta , 71, 4036-4043.

Gauthiez-Putallaz, L., Rubatto, D., and Hermann, J. (2016). Dating prograde fluid pulses during subduction by in situ $\mathrm{U}-\mathrm{Pb}$ and oxygen isotope analysis. Contrib. Mineral. Petrol. 171. doi:10.1007/s00410-015-1226-4

Geisler, T., Rashwan, A.A., Rahn, M.K.W., Poller, U., Zwingmann, H., Pidgeon, R.T., Schleicher, H., Tomaschek, F. (2003). Low temperature hydrothermal alteration of natural metamict zircons from the Eastern Desert, Egypt. Mineral. Mag., 67, 485-508. 
561

562

563

564

565

566

567

568

569

570

571

572

573

575

576

577

Geisler, T., Schaltegger, U., and Tomaschek, F. (2007). Re-equilibration of zircon in aqueous fluids and melts. Elements, 3, 43-50.

Gnos, E., Janots, E., Berger, A., Whitehouse, M., Walter, F., Pettke, T., and Bergemann, C. (2015). Age of cleft monazites in the eastern Tauern Window: constraints on crystallization conditions of hydrothermal monazite. Swiss J. Geosci. 108, 55-74.

Grand'homme, A., Janots, E., Bosse, V., Seydoux-Guillaume, A.M., de Ascenção, G. (2016a). Interpretation of $\mathrm{Th}-\mathrm{Pb}$ and $\mathrm{U}-\mathrm{Pb}$ in-situ ages of hydrothermal monazite: Evidence from a large-scale regional study in clefts from the western Alps. Mineralogy and Petrology doi:10.1007/s00710-016-0451-5.

Grand'Homme, A., Janots, E., Seydoux-Guillaume, A.-M., Guillaume, D., Bosse, V., and Magnin, V. (2016b). Partial resetting of the U-Th-Pb systems in experimentally altered monazite: Nanoscale evidence of incomplete replacement. Geology vol.44, p.439-442, doi:10.1130/G37770.1.

Gratz, R., and Heinrich, W. (1997). Monazite-xenotime thermobarometry: experimental calibration of the miscibility gap in the binary system $\mathrm{CePO}_{4}-\mathrm{YPO}_{4}$. Am. Mineral., 82, $772-780$.

Harlov, D.E., and Hetherington, C.J. (2010). Partial high-grade alteration of monazite using alkali-bearing fluids: Experiment and nature. Am. Mineral. 95, 1105-1108.

Harlov, D.E., Wirth, R., and Hetherington, C.J. (2011). Fluid-mediated partial alteration in monazite: the role of coupled dissolution-reprecipitation in element redistribution and mass transfer. Contrib. Mineral. Petrol. 162, 329-348.

Harrison, T.M., Catlos, E., and Montel, J.M. (2002). U-Th-. Pb dating of phosphate minerals. In Reviews in Mineralogy and Geochemistry (ed. P. H. Ribbe) 48, pp. 523-558. Mineralogical Society of America.

Heinrich, W., Andrehs, G., and Franz, G. (1997). Monazite-xenotime miscibility gap thermometry. I. An empirical calibration. J. Metamorph. Geol., 15, 3-16.

Hetherington, C.J., and Harlov, D.E. (2008). Metasomatic thorite and uraninite inclusions in xenotime and monazite from granitic pegmatites, Hidra anorthosite massif, southwestern Norway: Mechanics and fluid chemistry: American Mineralogist, 93, 806-820. 
588

589

590

591

592

593

594

595

596

597

598

599

600

601

602

603

604

605

606

607

608

609

610

611

612

613

614

615

616

617

Hetherington, C.J., Harlov, D.E., and Budzyn, B. (2010). Experimental metasomatism of monazite and xenotime: mineral stability, REE mobility and fluid composition. Mineral. Petrol. 99, 165-184.

Holder, R.M., Hacker, B.R., Kylander-Clark, A.R.C., and Cottle, J.M. (2015). Monazite traceelement and isotopic signatures of (ultra) high-pressure metamorphism: examples from the Western Gneiss Region, Norway. Chem. Geol., 409, 99-111.

Janots, E., Negro, F., Brunet, F., Goffé, B., Engi, M., and Bouybaouène, M.L. (2006). Evolution of the REE mineralogy in HP-LT metapelites of the Sebtide complex, Rif, Morocco: Monazite stability and geochronology. Lithos 87, 214-234.

Janots, E., Engi, M., Berger, A., Allaz, J., Schwarz, J.-O., and Spandler, C. (2008). Prograde metamorphic sequence of REE minerals in pelitic rocks of the Central Alps: implications for allanite-monazite-xenotime phase relations from 250 to 610 degrees C. J. Metamorph. Geol. 26, 509-526.

Janots, E., Berger, A., and Engi, M. (2011). Physico-chemical control on the REE minerals in chloritoid-grade metasediments from a single outcrop (Central Alps, Switzerland). Lithos $121,1-11$.

Janots, E., Berger, A., Gnos, E., Whitehouse, M., Lewin, E., and Pettke, T. (2012). Constraints on fluid evolution during metamorphism from $\mathrm{U}-\mathrm{Th}-\mathrm{Pb}$ systematics in Alpine hydrothermal monazite. Chem. Geol. 326-327, 61-71.

Kelly, N.M., Harley, S.L., and Möller, A. (2012). Complexity in the behavior and recrystallization of monazite during high-T metamorphism and fluid infiltration. Chem. Geol. 322-323:192-208.

Kirkland, C.L., Erickson, T.M., Johnson, T.E., Danišík, M., Evans, N.J., Bourdet, J., and McDonald, B.J. (2016). Discriminating prolonged, episodic or disturbed monazite age spectra: An example from the Kalak Nappe Complex, Arctic Norway. Chem. Geol. 424:96-110.

Kogawa, M., Watson, E.B., Ewing, R.C., and Utsunomiya, S. (2012). Lead in zircon at the atomic scale. Am. Miner., 97, 1094-1102.

Kramers, J., Frei, R., Newville, M., Kober, B., and Villa, I. (2009). On the valency state of radiogenic lead in zircon and its consequences. Chem. Geol., 261, 4-11. 
Krenn, E., Putz, H., Finger, F., and Paar, W.H. (2011). Sulfur-rich monazite with high common $\mathrm{Pb}$ in ore-bearing schists from the Schellgaden mining district (Tauern Window, Eastern Alps). Mineral. Petrol. 102:51-62.

Kusiak, M.A., Dunkley, D.J., Wirth, R., Whitehouse, M.J., Wilde, S.A., and Marquardt, K. (2015). Metallic lead nanospheres discovered in ancient zircons. PNAS, 112, 4958-4963.

Kusiak, M.A., Whitehouse, M.J., Wilde, S.A., Nemchin, A.A., and Clark, C. (2013). Mobilization of radiogenic $\mathrm{Pb}$ in zircon revealed by ion imaging: Implications for early Earth geochronology. Geology, 41, 291-294.

Laurent AT, Seydoux-Guillaume AM, Duchene S., Bingen B., Bosse V., and Datas L. (2016). Sulphate incorporation in monazite lattice and dating the cycle of sulphur in metamorphic belts. Contrib. Miner. Petrol., DOI 10.1007/s00410-016-1301-5.

Lee, J.K.W., Williams, I.S., and Ellis, D.J. (1997). Pb, U and Th diffusion in natural zircon. Nature 390, 159-162.

Marsh, J.H., and Stockli, D.F. (2015). Zircon U-Pb and trace element zoning characteristics in an anatectic granulite domain: Insights from LASS-ICP-MS depth profiling: Lithos, 239, 170-185.

McFarlane, C. R., and McKeough, M. (2013). Petrogenesis of the Kulyk Lake monaziteapatite-Fe (Ti)-oxide occurrence revealed using in-situ LA-(MC)-ICP-MS trace element mapping, U-Pb dating, and $\mathrm{Sm}-\mathrm{Nd}$ isotope systematics on monazite. Am. Miner., 98, 1644-1659.

Meldrum, A., Boatner, L.A.,Weber,W.J., Ewing, R.C. (1998). Radiation damage in zircon and monazite. Geochim. Cosmochim. Acta, 62, 2509-2520.

Montel, J.-M., Devidal, J.-L., and Avignant, D. (2002). X-ray diffraction study of brabantitemonazite solid solution. Chem. Geol., 191:89-104.

Moser, D.E., Davis, W.J., Reddy, S.M., Flemming, R.L., and Hart, R.J. (2009). Zircon U-Pb strain chronometry reveals deep impact triggered flow: Earth Planet. Sci. Lett., 277, 73-79.

Muhling, J.R., Fletcher, I.R., Rasmussen, B. (2012). Dating fluid flow and Mississippi Valley type base-metal mineralization in the Paleoproterozoic Earaheedy Basin, Western Australia. Precambrian Res., 212-213, 75-90. 
Nasdala, L., Hanchar, J.M., Rhede, D., Kennedy, A.K., Váczi, T. (2010). Retention of uranium in complexly altered zircon: an example from Bancroft, Ontario. Chem. Geol., 269, 290-300.

Nemchin, A.A., Horstwood, M.S.A., and Whitehouse, M.J. (2013). High-spatial-Resolution Geochronology. Elements, 9, 31-37.

Ni, Y., Hughes, J.M., and Mariano, A.N. (1995). Crystal chemistry of the monazite and xenotime structures. Am. Mineral., 80, 21-26.

Ondrejka, M., Uher, P., Pršek, J., Ozdín, D. (2007). Arsenian monazite-(Ce) and xenotime(Y), REE arsenates and carbonates from the Tisovec-Rejkovo rhyolite, Western Carpathians, Slovakia: Composition and substitutions in the $(\mathrm{REE}, \mathrm{Y}) \mathrm{XO}_{4}$ system $(\mathrm{X}=\mathrm{P}$, As, Si, Nb, S). Lithos, 95, 116-129.

Parrish, R.R. (1990). U-Pb dating of monazite and its application to geological problems. Can. J. Earth Sci., 27, 1431-1450.

Peterman, E.M., Reddy, S.M., Saxey, D.W., Snoeyenbos, D.R., Rickard, W.D.A., Fougerouse, D., and Kylander-Clark, A.R.C. (2016). Nanogeochronology of discordant zircon measured by atom probe microscopy of $\mathrm{Pb}$-enriched dislocation loops. Sci. Adv., 2016, 2: e1601318.

Piazolo, S., La Fontaine, A., Trimby, P., Harley, S., Yang, L., Armstrong, R., and Cairney, J. M. (2016). Deformation induced trace element redistribution in zircon revealed using atom probe tomography. Nat. Commun. 7, 10490.

Pidgeon RT, O’Neil JR, and Silver RT (1995). The interdependence of U-Pb stability, crystallinity and external conditions in natural zircons - an early experimental study. In: Leon T. Silver 70th Birthday Symposium and Celebration, Extended Abstracts, 225-231.

Pidgeon, R. (2014). Zircon radiation damage ages. Chem. Geol., 367, 13-22.

Pidgeon, R.T., O’Neil, J.R., and Silver, R.T. (1966). Uranium and lead isotopic stability in a metamict zircon under experimental hydrothermal conditions. Science, 154, 1538-1540.

Poitrasson, F., Chenery, S., Bland, D.J. (1996): Contrasted monazite hydrothermal alteration mechanisms and their geochemical implications for the U-Th-Pb geochronology and nuclear ceramics. Earth Planet. Sci. Let., 145, 79-96. 
Poitrasson, F., Chenery, S., Shepherd, T.J. (2000): Electron microprobe and LA-ICP-MS study of monazite hydrothermal alteration: implications for the U-Th-Pb geochronology and nuclear ceramics. Geochim. Cosmochim. Acta, 64, 3283-3297.

Prsek, J., Ondrejka, M., Bacik, P., Budzyn, B., and Uher, P. (2010). Metamorphichydrothermal REE minerals in the Bacuch magnetite deposit, Western Carpathians, Slovakia: (S, Sr)-rich monazite-(Ce) and Nd-dominant hingganite. Can. Mineral., 48, 8194.

Putnis, A. (2009). Mineral replacement reactions. Reviews in Mineralogy and Geochemistry, $70,87-124$.

Putnis, A., and Putnis, C.V. (2007). The mechanism of reequilibration of solids in the presence of a fluid phase. J. Solid State Chem. 180, 1783-1786.

Pyle, J.M., Spear, F.S., Rudnick, R.L., and McDonough, W.F. (2001). Monazite-xenotimegarnet equilibrium in metapelites and a new monazite-garnet thermometer. J. Petrol., 42, 2083-2107.

Rasmussen, B., and Muhling, J.R. (2007). Monazite begets monazite: evidence for dissolution of detrital monazite and reprecipitation of syntectonic monazite during low-grade regional metamorphism. Contrib. Mineral. Petrol., 154, 675-689.

Rasmussen, B., Fletcher, I.R., and McNaughton, N.J. (2001). Dating low-grade metamorphic events by SHRIMP U-Pb analysis of monazite in shales. Geology, 29, 963-966.

Rasmussen, B., Fletcher, I.R., Muhling, J.R., Gregory, C.J., and Wilde, S.A. (2011). Metamorphic replacement of mineral inclusions in detrital zircon from Jack Hills, Australia: Implications for the Hadean Earth. Geology, 39, 1143-1146.

Rubatto, D., Williams, S.I., and Buick, S.I. (2001). Zircon and monazite response to prograde metamorphism in the Reynolds Range, central Australia. Contrib. Mineral. Petrol. 140, 458-468. doi:10.1007/PL00007673

Rubatto, D., Chakraborty, S., and Dasgupta, S. (2013). Timescales of crustal melting in the Higher Himalayan Crystallines (Sikkim, Eastern Himalaya) inferred from trace elementconstrained monazite and zircon chronology. Contrib. Mineral. Petrol. 165, 349-372.

Salje, E.K.H., Chrosch, J., and Ewing, R.C. (1999). Is "metamictization" of zircon a phase transition? Am. Mineral., 84, 1107-1116. 
Schoene, B., Condon, D.J., Morgan, L. and McLean, N. (2013). Precision and Accuracy in Geochronology. Elements, 9, 19-24.

Seydoux-Guillaume, A.M., Bingen, B., Paquette, J.L., and Bosse, V. (2015). Nanoscale evidence for uranium mobility in zircon and the discordance of $\mathrm{U}-\mathrm{Pb}$ chronometers. Earth Planet. Sci. Lett., 409, 43-48.

Seydoux-Guillaume, A.-M., Goncalves, P., Wirth, R., and Deutsch, A. (2003). Transmission electron microscope study of polyphase and discordant monazites: Site-specific specimen preparation using the focused ion beam technique. Geology 31, 973-976.

Seydoux-Guillaume, A.-M., Montel, J.-M., Bingen, B., Bosse, V., de Parseval, P., Paquette, J.-L., Janots, E., Wirth, R. (2012). Low-temperature alteration of monazite: Fluid mediated coupled dissolution-precipitation, irradiation damage, and disturbance of the $\mathrm{U}-\mathrm{Pb}$ and Th-Pb chronometers. Chem Geol, 330-331:140-158.

Seydoux-Guillaume, A.-M., Paquette, J.-L., Wiedenbeck, M., Montel, J.-M., and Heinrich, W. (2002a). Experimental resetting of the $\mathrm{U}-\mathrm{Th}-\mathrm{Pb}$ systems in monazite. Chem Geol, 191:165-181.

Seydoux-Guillaume, A.M., Wirth, R., and Ingrin, J. (2007). Contrasting response of $\mathrm{ThSiO}_{4}$ and monazite to natural irradiation. Eur. J. Mineral., 19, 7-14.

Seydoux-Guillaume, A.M., Wirth, R., Deutsch, A., and Schärer, U. (2004). Microstructure of 24-1928 Ma concordant monazites: implications for geochronology and nuclear waste deposits. Geoch. Cosmochim. Acta, 68, 2517-2527.

Seydoux-Guillaume, A.-M., Wirth, R., Heinrich, W., and Montel, J.-M. (2002b). Experimental determination of the Th partitioning between monazite and xenotime using Analytical Electron Microscopy and X-ray Diffraction Rietveld analysis. Eur. J. Mineral., $14,869-878$.

Shazia, J.R., Harlov, D.E., Suzuki, K., Kim, S.W., Girish-Kumar, M., Hayasaka, Y., IshwarKumar, C., Windley, B.F., and Sajeev, K. (2015). Linking monazite geochronology with fluid infiltration and metamorphic histories: Nature and experiment. Lithos 236-237, 1-15.

Sinha, A.K., Wayne, D.M, and Hewitt, D.A. (1992). The hydrothermal stability of zircon: preliminary experimental and isotopic studies. Geochim. Cosmochim. Acta, 56, 35353551. 
Spear, F.S., and Pyle, J.M. (2002). Apatite, Monazite, and Xenotime in metamorphic rocks. In Reviews in Mineralogy and Geochemistry (ed. P. H. Ribbe) 48, pp. 293-335. Mineralogical Society of America.

Tanaka, K., Takahashi, Y., Horie, K., Shimizu, H., and Murakami, T. (2010). Determination of the oxidation state of radiogenic $\mathrm{Pb}$ in natural zircon using X-ray absorption near-edge structure. Phys. Chem. Miner., 37, 249-254.

Teufel, S., and Heinrich, W. (1997). Partial resetting of the U-Pb isotope system in monazite through hydrothermal experiments: an SEM and U-Pb isotope study. Chem. Geol., 137, 273-281.

Trachenko, K., Dove, M.T., and Salje, E.K.H. (2003). Structural changes in zircon under $\alpha-$ decay irradiation. Phys. Rev., 65, 180102(R).

Utsunomiya, S., Palenik, C.S., Valley, J.W., Cavosie, A.J., Wilde, S.A., Ewing, R.C. (2004). Nanoscale occurrence of $\mathrm{Pb}$ in an Archean zircon. Geochim. Cosmochim. Acta, 68, 46794686.

Utsunomiya, S., Valley, J.W., Cavosie, A.J., Wilde, S.A., and Ewing, R.C. (2007). Radiation damage and alteration of zircon from a $3.3 \mathrm{Ga}$ porphyritic granite from the Jack Hills, Western Autralia. Chem. Geol., 236, 92-111.

Valley, J.W., Cavosie, A.J., Ushikubo, T., Reinhard, D.A., Lawrence, D.F., Larson, D.J., Clifton, P.H., Kelly, T.F., Wilde, S.A., Moser, D.E., Spicuzza, M.J. (2014). Hadean age for a post-magma-ocean zircon confirmed by atom-probe tomography. Nat. Geosci.,7, 219223.

Valley, J. W., Reinhard, D.A., Cavosie, A.J., Ushikubo, T., Lawrence, D.F., Larson, D.J., Kelly, T.F., Snoeyenbos, D.R., and Strickland, A. (2015). Nano-and micro-geochronology in Hadean and Archean zircons by atom-probe tomography and SIMS: New tools for old minerals. Am. Mineral. 100, 1355-1377.

Villa, I.M., and Williams, M.L. (2013). Geochronology of metasomatic events. In: Harlov D \& Austrheim H (eds) Metasomatism and the Chemical Transformation of Rock: the role of fluids in terrestrial and extraterrestrial processes. Springer, Berlin, pp 171-202. 
Wang, J.-M., Rubatto, D., and Zhang, J.-J. (2015). Timing of Partial Melting and Cooling across the Greater Himalayan Crystalline Complex (Nyalam, Central Himalaya): Insequence Thrusting and its Implications. J. Petrol. 56, 1677-1702.

Wawrzenitz, N., Krohe, A., Rhede, D., and Romer, R.L. (2012). Dating rock deformation with monazite: The impact of dissolution precipitation creep. Lithos, 134-135, 52-74.

Whitehouse, M.J., Kumar, G.R.R., and Rimša, A. (2014). Behaviour of radiogenic Pb in zircon during ultrahigh-temperature metamorphism: An ion imaging and ion tomography case study from the Kerala Khondalite Belt, southern India. Contrib. Mineral. Petrol., 168, $1-18$.

Whitney, J. (1984). Fugacities of sulfurous gases in pyrrhotite-bearing silicic magmas. Am. Mineral., 69, 69-79.

Williams, M.L., Jercinovic, M.J., and Terry, M.P. (1999). Age mapping and dating of monazite on the electron microprobe: Deconvoluting multistage tectonic histories. Geology, 27, 1023-1026.

Williams, M.L., Jercinovic, M.J., and Hetherington, C.J. (2007). Microprobe Monazite Geochronology: Understanding Geologic Processes by Integrating Composition and Chronology. Annu. Rev. Earth Planet. Sci., 35, 137-175.

Williams, M.L., Jercinovic, M.J., Harlov, D.E., Budzyń, B., and Hetherington, C.J. (2011). Resetting monazite ages during fluid-related alteration: Chem. Geol., 283, 218-225.

Williams, M.L., and Jercinovic, M.J. (2012). Tectonic interpretation of metamorphic tectonites: integrating compositional mapping, microstructural analysis and in situ monazite dating. J. Metamorph. Geol. 30, 739-752.

Wirth, R. (2004). Focused Ion Beam (FIB): a novel technology for advanced application of micro- and nanoanalysis in geosciences and applied mineralogy. Eur. J. Mineral., 16, 863877.

Wirth, R. (2009). Focused Ion Beam (FIB) combined with SEM and TEM: advanced analytical tools for studies of chemical composition, microstructure and crystal structure in geomaterials on a nanometer scale. Chem. Geol., 261, 217-229.

Xu, X.S., Zhang, M., Zhu, K.Y., Chen, X.M., He, Z.Y. (2012). Reverse age zonation of zircon formed by metamictisation and hydrothermal fluid leaching. Lithos 150, 256-267. 
Yakymchuk, C., and Brown, M. (2014). Behaviour of zircon and monazite during crustal melting: J. Geol. Soc. London, 171, 465-479.

\section{Figure captions}

\section{Figure 1}

Transmission Electron Microscope (TEM) images from U- or Th-rich-nano-phases in various accessory minerals. A-Bright-Field (BF) TEM and B-Dark-Field (DF) TEM images of $\mathrm{ThSiO}_{4}$ exsolutions (arrows) in apatite. C- Scanning TEM of uraninite $\left(\mathrm{UO}_{2}\right)$ nanocrystals (arrow) in porous zircon crystal from the Evje-Iveland pegmatite field in Norway [modified from Seydoux-Guillaume et al., 2015). D- BF-TEM of nano-crack filled with $\mathrm{ThSiO}_{4}$ in monazite (mnz) crystal from Madagascar [modified from Seydoux-Guillaume et al., 2012). hmt: hematite.

\section{Figure 2}

A- Tera-Wasserburg Concordia diagram and $\mathrm{B}-{ }^{207} \mathrm{~Pb} /{ }^{206} \mathrm{~Pb}$ ratio images of zircon grains from sample 16178-2 from Napier complex, East Antarctica, analyzed using Secondary Ion Mass Spectrometry (SIMS) [modified from Kusiak et al., 2013]. C- High Angle Annular Dark Field (HAADF) TEM image and D- High Resolution TEM image of Pb nanosphere in zircon crystal from the same sample [modified from Kusiak et al., 2015].

\section{Figure 3}

A- Tera-Wasserburg Concordia diagram for 9 zircon crystals included in plagioclase and in xenotime crystals from the Evje-Iveland pegmatite field in Norway. Most points are scattering along two discordia lines (blue for zircon included in plagioclase and yellow for zircon included in xenotime) with intercepts having little geological significance. B- Back Scattered Electron (BSE) image from one zircon (zrn) crystal included in plagioclase (plg) with position extraction of the Focused Ion Beam (FIB) foil. C- STEM-HAADF image from FIB3 foil cut from zircon crystal in $\mathrm{B}$ and the corresponding U-chemical map (D) showing close 
association of $\mathrm{UO}_{2}$ nanocrystals (bright points in $\mathrm{C}$ ) within nanopores (black in $\mathrm{C}$ ). Modified from Seydoux-Guillaume et al. [2015].

\section{Figure 4}

A- Weighted histogram of 448 Electron Microprobe (EPMA) chemical U-Th-Pb ages for 26 monazite crystals included in garnet, quartz and coronitic textures from the Andriamena unit in Madagascar. B- BF-TEM image of FIB foil cut in monazite core showing EPMA age dispersion (911-1805 Ma). Note dark domains 2, with one in a nano-pore that probably correspond to fluid inclusion. Monazite matrix (1) revealed also typical mottled diffraction contrasts due to distorted volumes in monazite lattice in response to radiation damage. $\mathrm{C}$ : Overlay of analysis of monazite matrix (1) and representative Energy Dispersive X-Ray (EDS) analysis of dark domain (2) in B. Compared to monazite matrix, dark domains are very enriched in $\mathrm{Pb}$ and, to lesser extent, in $\mathrm{Ca}$ and $\mathrm{Si}$. $\mathrm{REE}$ - rare earth elements. Modified from Seydoux-Guillaume et al. [2003].

\section{Figure 5}

A- EPMA dating in mnzl $(554 \pm 11 \mathrm{Ma})$ and altered rims (alt mnz in B) of monazite grains altered at $500^{\circ} \mathrm{C}$ (B). In altered domains, ages spread in the range of 40-440 Ma, with a weighted average age of $163 \pm 54 \mathrm{Ma}$, due to incomplete replacement of mnz1 by a secondary monazite (mnz2) within the altered rim and the analysis of a nano-mixture of different proportions of mnz1 vs mnz2 in the analyzed volume (C). MSWD - mean square of weighted deviates. B- BSE image of monazite grain altered during an hydrothermal experiment at $500^{\circ} \mathrm{C}, 2$ kbar, 114 days with $\mathrm{NaOH}(1 \mathrm{M})$, and mounted in epoxy. alt mnz: domain of the monazite grain that has been altered during experiment; mnz1: unreacted grain. FIB: location of the foil seen in C. C- STEM-HAADF image of FIB foil cut from B. Dash line show the interaction domain when using EPMA analyses $(25 \mathrm{kV})$. mnz2: secondary monazite, free of $\mathrm{Pb}$, formed during experiment and only visible at the nanoscale. Pt: platinum deposit for FIB preparation. Modified from Grand'homme et al. [2016b].

\section{Figure 6}


851 A- BSE image from one monazite grain with 3 domains (D1-D3) defined by different 852 compositions. D1: S-rich (0.45-0.72 Wt. \% SO2) monazite core with Th incorporated as 853 cheralite $\left[\mathrm{CaTh}\left(\mathrm{PO}_{4}\right)_{2}\right]$ component; D2: S-bearing domain $\left(\mathrm{SO}_{2}>0.05 \mathrm{Wt} . \%\right)$ partly clouded 854 with solid inclusions (black points in A) and D3: S-free, Y and Th-rich domains with Th 855 accommodated as huttonite $\left(\mathrm{ThSiO}_{4}\right)$ component. FIB foil (E-F) was cut in domain D1. B-D $856 \mathrm{U}-\mathrm{Pb}$ data presented in Tera-Wasserburg plots. B- all analyses. C-all analyses with colour 857 coding corresponding to $\mathrm{SiO}_{2}$ concentrations (in Wt.\%) measured by EPMA prior to laser 858 ablation. D- Same figure with color coding for $\mathrm{SO}_{2}$ concentrations. E-F: STEM-HAADF 859 images of foil cut in D1 (A). E- low magnification image reveals black dots (1) corresponding 860 to negative density contrasts in monazite core D1 (2). EDS analysis demonstrated that they 861 correspond to $\mathrm{CaSO}_{4}$-rich nanocluster (not shown). F- High-resolution image in zone axis 862 [101] of one $\mathrm{CaSO}_{4}$ nanocluster $(\sim 5-10 \mathrm{~nm})$ in monazite lattice. Bright spots in E corresponds 863 to Ga implantation during sample preparation. 


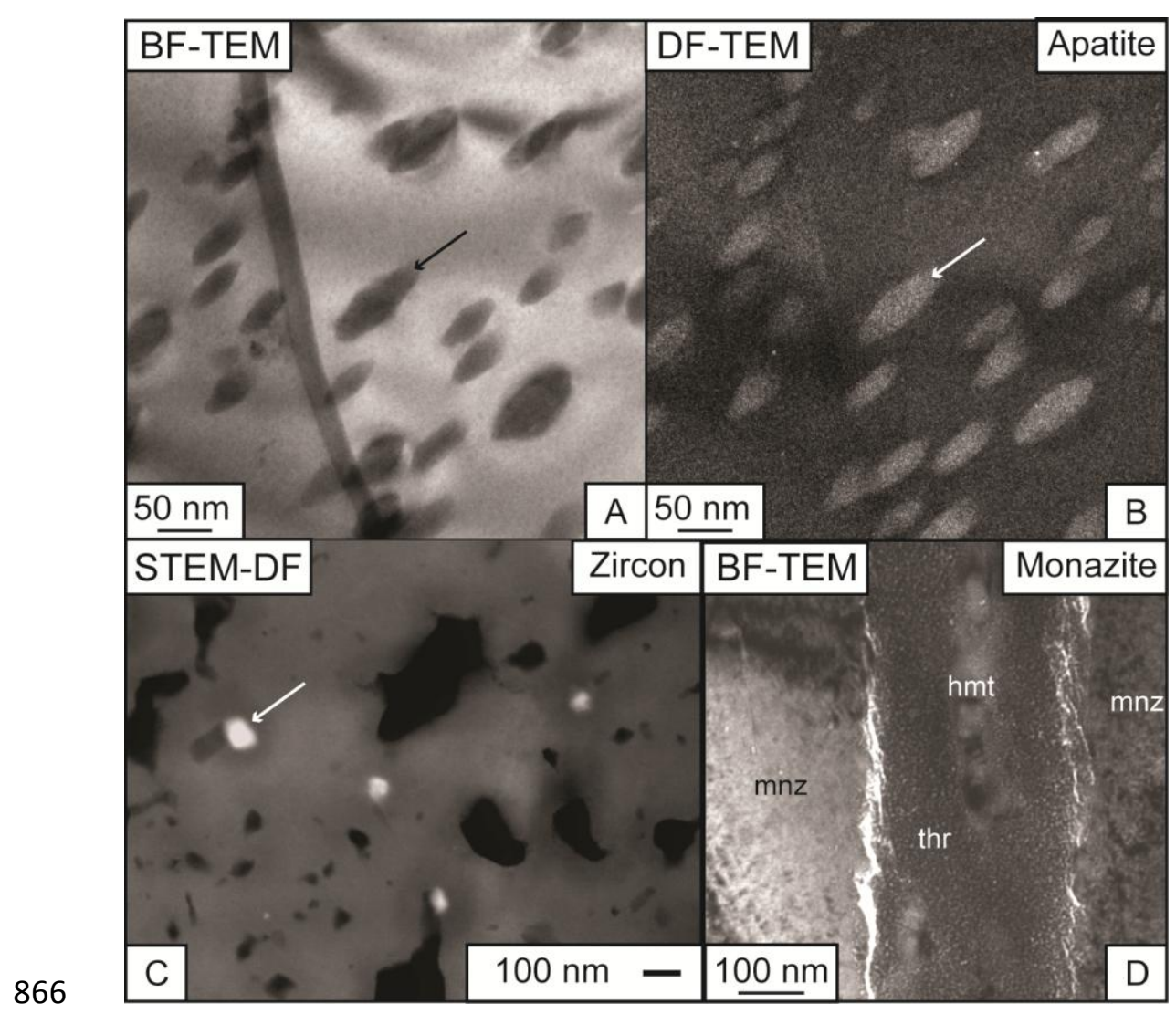

867 Figure 1
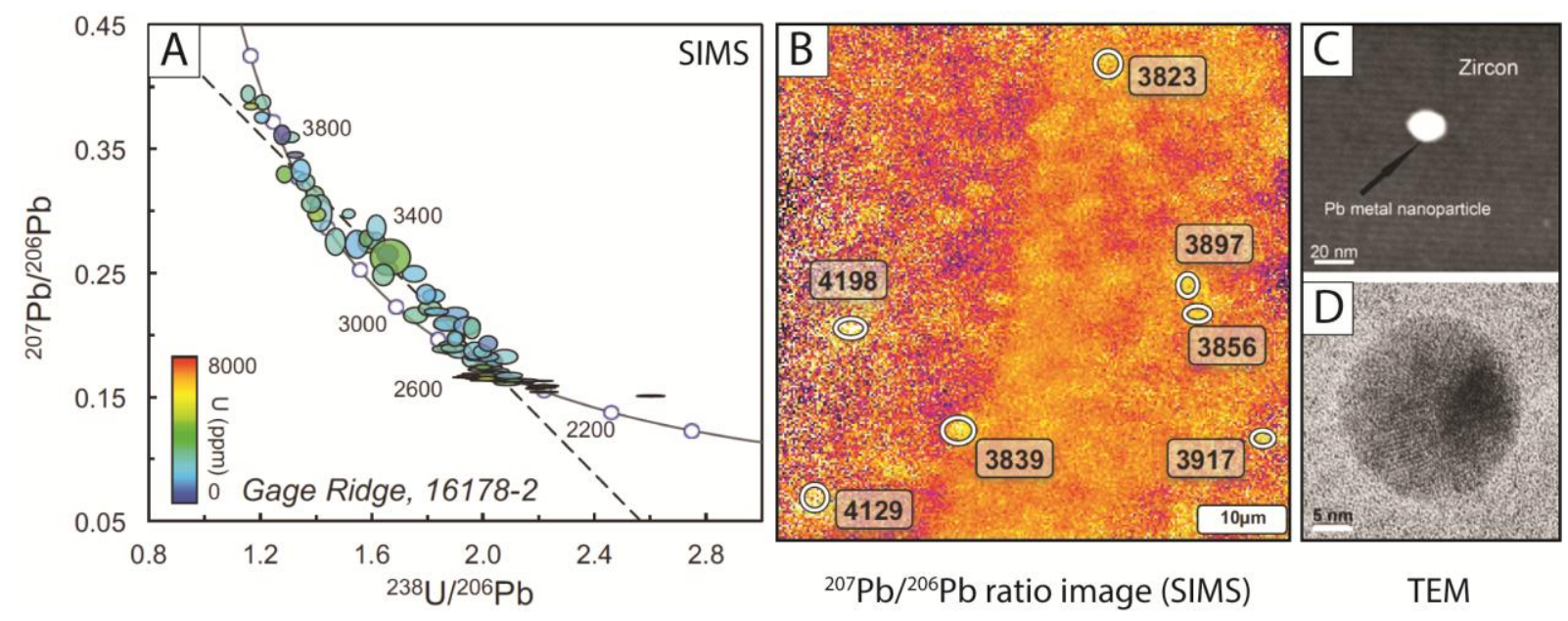

869

Figure 2 

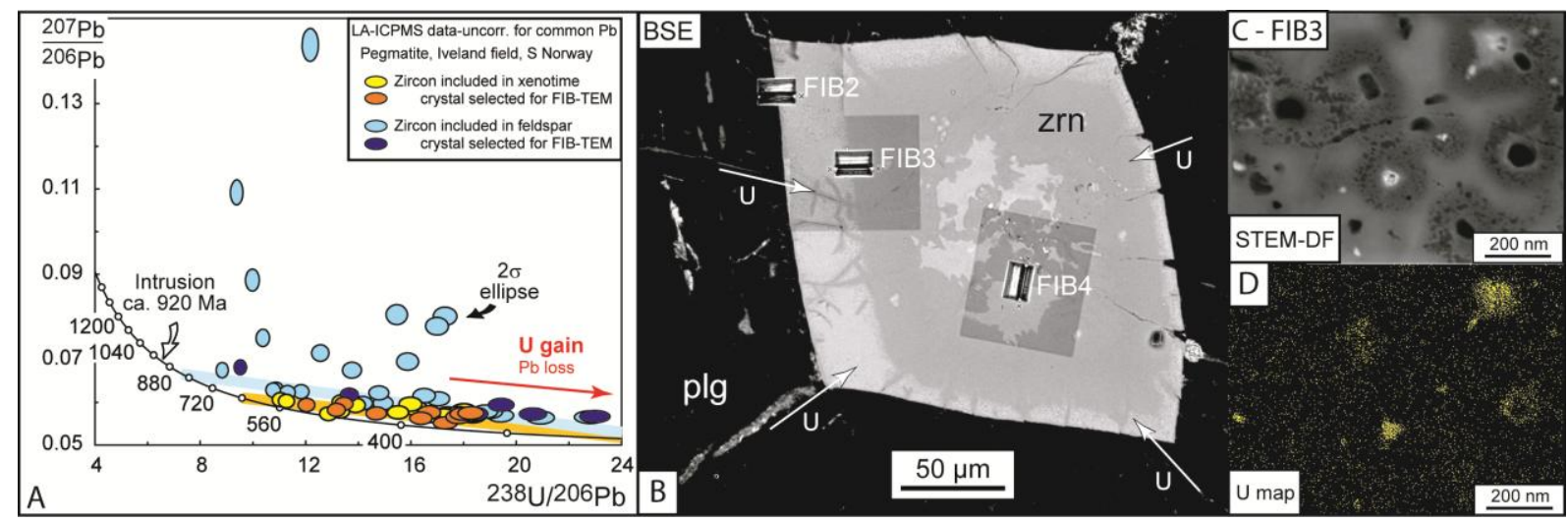

$871 \quad$ Figure 3

872
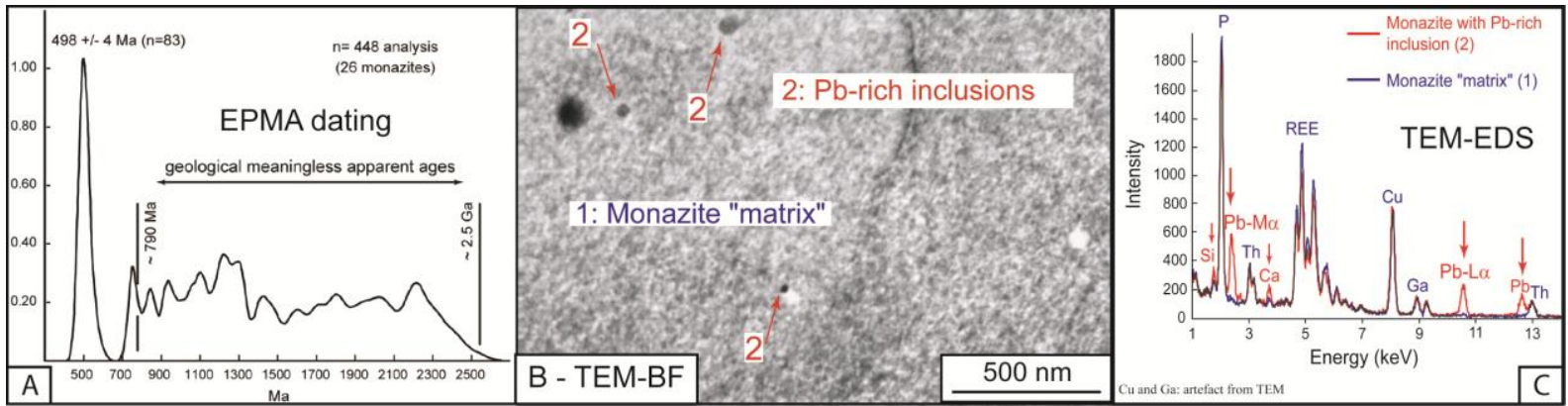

$873 \quad$ Figure 4
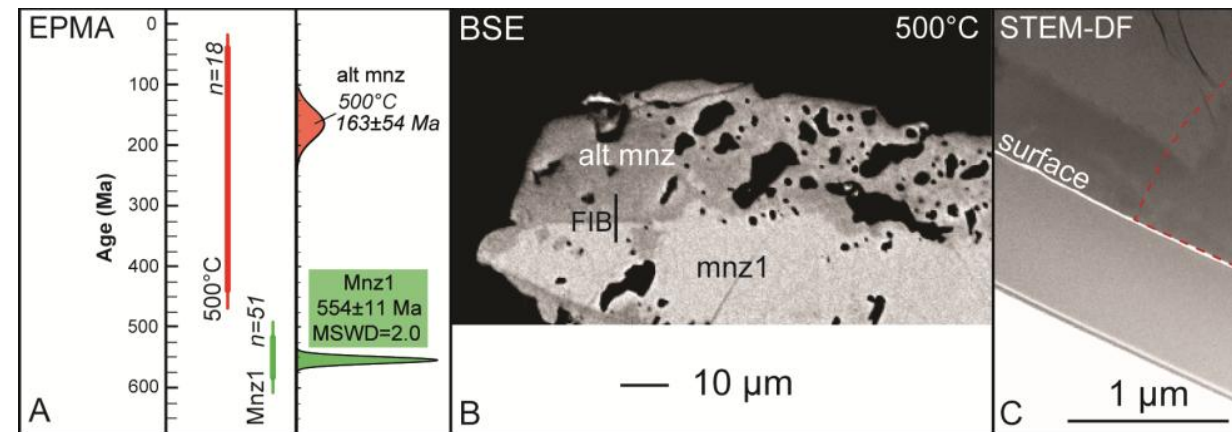

mnz1

875

Figure 5 

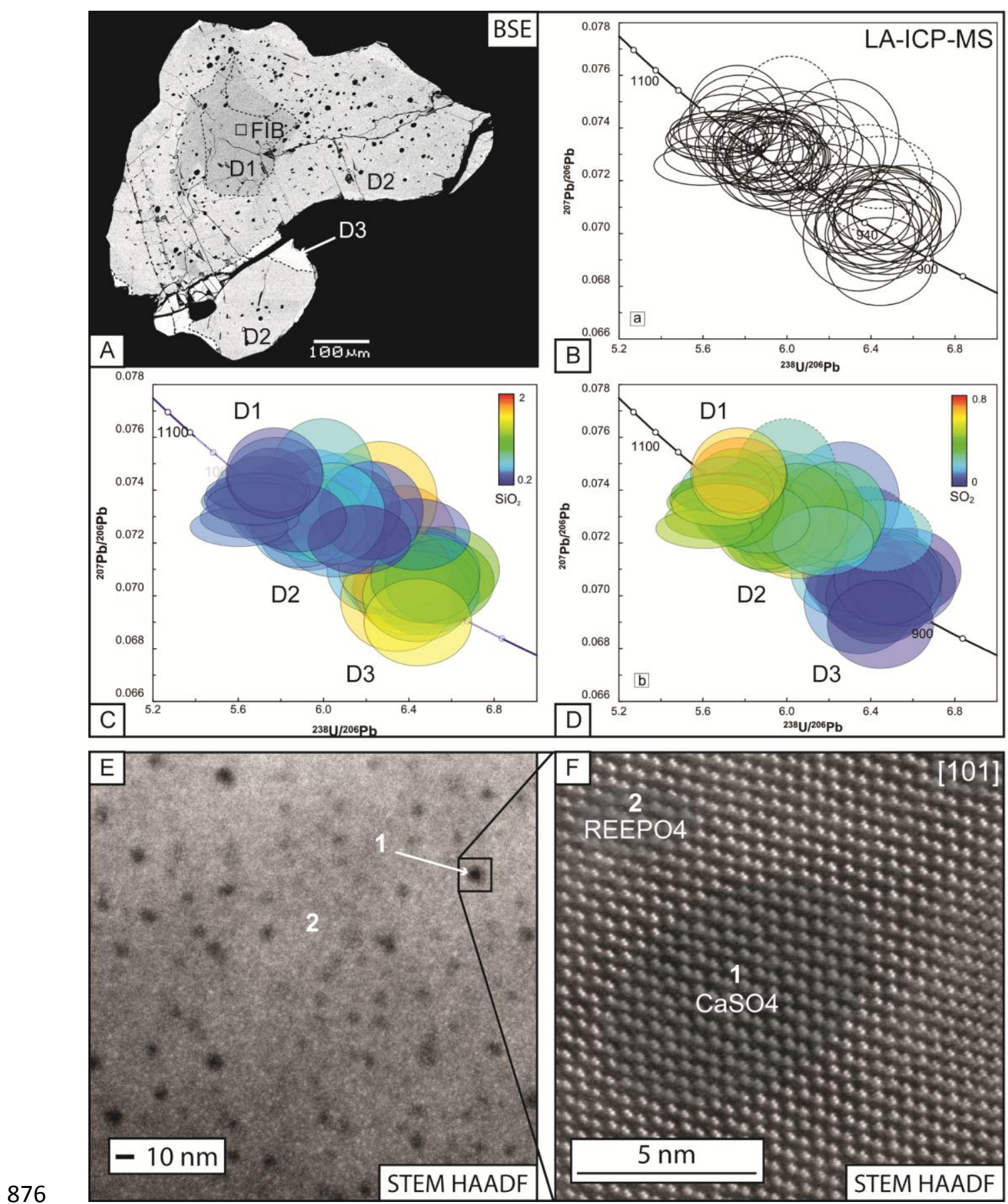

$877 \quad$ Figure 6 